\title{
QTL mapping of adult plant and seedling resistance to leaf rust (Puccinia triticina Eriks.) in a multiparent advanced generation intercross (MAGIC) wheat population
}

\author{
Sandra Rollar ${ }^{1}\left[\right.$ - Albrecht Serfling ${ }^{1} \cdot$ Manuel Geyer $^{2} \cdot$ Lorenz Hartl $^{2} \cdot$ Volker Mohler $^{2} \cdot$ Frank Ordon $^{1}$
}

Received: 16 May 2020 / Accepted: 28 July 2020 / Published online: 19 August 2020

(c) The Author(s) 2020

\begin{abstract}
Key message The Bavarian MAGIC Wheat population, comprising 394 F6:8 recombinant inbred lines was phenotyped for Puccinia triticina resistance in multi-years' field trials at three locations and in a controlled environment seedling test. Simple intervall mapping revealed 19 QTL, corresponding to 11 distinct chromosomal regions.

Abstract The biotrophic rust fungus Puccinia triticina is one of the most important wheat pathogens with the potential to cause yield losses up to $70 \%$. Growing resistant cultivars is the most cost-effective and environmentally friendly way to encounter this problem. The emergence of leaf rust races being virulent against common resistance genes increases the demand for wheat varieties with novel resistances. In the past decade, the use of complex experimental populations, like multiparent advanced generation intercross (MAGIC) populations, has risen and offers great advantages for mapping resistances. The genetic diversity of multiple parents, which has been recombined over several generations, leads to a broad phenotypic diversity, suitable for high-resolution mapping of quantitative traits. In this study, interval mapping was performed to map quantitative trait loci (QTL) for leaf rust resistance in the Bavarian MAGIC Wheat population, comprising $394 \mathrm{~F}_{6: 8}$ recombinant inbred lines (RILs). Phenotypic evaluation of the RILs for adult plant resistance was carried out in field trials at three locations and two years, as well as in a controlled-environment seedling inoculation test. In total, interval mapping revealed 19 QTL, which corresponded to 11 distinct chromosomal regions controlling leaf rust resistance. Six of these regions may represent putative new QTL. Due to the elite parental material, RILs identified to be resistant to leaf rust can be easily introduced in breeding programs.
\end{abstract}

Communicated by Urmil Bansal.

Electronic supplementary material The online version of this article (https://doi.org/10.1007/s00122-020-03657-2) contains supplementary material, which is available to authorized users.

Frank Ordon

frank.ordon@julius-kuehn.de

Sandra Rollar

sandra.rollar@julius-kuehn.de

1 Institute for Resistance Research and Stress Tolerance, Julius Kuehn-Institute, Erwin Baur-Straße 27, 06484 Quedlinburg, Germany

2 Bavarian State Research Center for Agriculture, Institute for Crop Science and Plant Breeding, Am Gereuth 8, Freising, Germany

\section{Introduction}

With approximately 219 million hectares worldwide and $30 \%$ of global major cereal crop production in 2017 , wheat (Triticum spp.) belongs to the most important crops for human nutrition (Braun et al. 2010; FAO 2019). Leaf rust, caused by the obligate biotrophic fungus Puccinia triticina Eriks., is nowadays the most destructive and prevalent rust pathogen in wheat (Kolmer 2005). Due to its adaptation to a wide range of different environments, leaf rust occurs in many wheat-producing areas of the temperate zone, causing yield losses up to 70\% (Aktar-Uz-Zaman et al. 2017; Herrera-Foessel et al. 2006; Marasas et al. 2004). Although the application of fungicides helps to avoid yield losses, the deployment of resistant cultivars is the most effective, economic, and environmentally friendly approach to manage this disease. For wheat leaf rust, both qualitative and quantitative resistances are known. Seedling/qualitative resistance is monogenically inherited and only effective 
against a subset of races. Thus, it mainly follows the genefor-gene concept, in which resistance depends on a specific genetic interaction between host-resistance genes and avirulence genes of the pathogen (Flor 1956, 1971). These major genes confer vertical resistance and tend to be expressed from seedling to adult plant stages. Genotypes carrying such resistances show a hypersensitive response or programmed cell death (Bolton et al. 2008). In contrast, quantitative resistance is based on minor genes encoding various resistance responses, which are not restricted to specific pathogen races. Quantitative resistances are effective at later growth stages and are therefore referred to as field resistance or adult plant resistance (APR, Krattinger and Keller 2016). To date, more than 80 resistance genes to leaf rust ( $L r$ genes) have been identified in bread wheat, durum wheat, and diploid wheat species (Gill et al. 2019). While most of them show race-specific resistance at the seedling stage, genes like Lr12, Lr13, Lr22a/b, Lr34, Lr35, Lr37, Lr46, Lr67, Lr68, and $L r 77$ confer resistance at the adult plant stage (Dakouri et al. 2013; McIntosh et al. 2013, 2017).

The identification of such resistance genes as well as of quantitative trait loci (QTL) has been mainly based on biparental crosses (Huang et al. 2012). The weakness of such populations is the narrow genetic variation and the fact that genetic recombination is limited, which leads to a lower map resolution (Bandillo et al. 2013). Nowadays, high-throughput marker systems are available and genetic marker information is no longer limiting (Bayer et al. 2017; Chen et al. 2014; Cui et al. 2017; He et al. 2014; Mammadov et al. 2012), but the genetic variation present in respective populations (Asimit and Zeggini 2010; Gibson 2012). Thus, complex experimental populations such as nested association mapping (NAM, Yu et al. 2008) and multiparent advanced generation intercross (MAGIC) populations have been developed to detect QTL with a better reliability (Cavanagh et al. 2008). First multiparental intermated populations were exploited in mice (Churchill et al. 2004) and Drosophila melanogaster (King et al. 2012). In plants, MAGIC populations were first developed and described in studies regarding Arabidopsis thaliana (Cavanagh et al. 2008; Kover et al. 2009). These experimental designs involved multiple intercrosses of inbred founders for several generations to combine the genetic variation of all parental lines in the resulting progeny (Huang et al. 2012). MAGIC populations have been widely used to conduct QTL mapping in several crop species, such as rice (Bandillo et al. 2013), maize (Dell'Acqua et al. 2015), tomato (Pascual et al. 2015), faba bean (Sallam and Martsch 2015), sorghum (Ongom and Ejeta 2018), barley (Sannemann et al. 2015), and wheat (Gardner et al. 2016; Huang et al. 2012; Mackay et al. 2014; Milner et al. 2016; Sannemann et al. 2018). There are two clear advantages of using multiparental populations. First, based on the choice of founders, more traits of interest from each founder can be analyzed. Second, due to the higher genetic variability and recombination rate, QTL detection can be performed with increased precision and resolution (Bandillo et al. 2013; Cavanagh et al. 2008).

The Bavarian MAGIC Wheat population (BMWpop) is one of only two German MAGIC wheat populations, which are mainly based on adapted German elite cultivars. It captures $71.7 \%$ of the allelic diversity available in the German wheat breeding gene pool (Stadlmeier et al. 2018). These populations provide the potential to carry out genetic studies of important economical traits, such as plant height and resistance to powdery mildew (Sannemann et al. 2018; Stadlmeier et al. 2018). In addition, Stadlmeier et al. (2019) detected six, seven and nine QTL for resistance to important fungal pathogens, i.e., Blumeria graminis, Zymoseptoria tritici, and Pyrenophora tritici-repentis, respectively. The objectives of the current study were to (1) phenotype the BMW population for quantitative and qualitative leaf rust resistance in multi-environment field trials and an extensive seedling test and (2) genetically map QTL in order to develop closely linked molecular markers suitable for marker-assisted selection (MAS).

\section{Material and methods}

\section{Plant material}

The study is based on the multiparental BMW population comprising elite wheat cultivars (Stadlmeier et al. 2018). It consists of 394 diverse $\mathrm{F}_{6: 8}$ recombinant inbred lines (RILs), which were derived from a simplified eight founder MAGIC mating design with additional eight-way intercrosses. The founders 'Event', 'BAYB4535', 'Potenzial', 'Bussard', 'Firl3565', 'Format', 'Julius' and 'Ambition' originated from German and Danish wheat breeders and were selected on the criteria of (1) variation for agronomic, quality and disease resistance traits, (2) originating from different breeding programs, and (3) being important cultivars in the respective baking quality group. More detailed information about the development and the genetics of the BMW population is provided by Stadlmeier et al. (2018).

\section{Phenotypic assessment of leaf rust resistance in field}

Five field trials were performed, each using a randomized incomplete block design with two replications at three locations in Germany: Quedlinburg (QLB, 51 ${ }^{\circ} 46^{\prime} 21.45^{\prime \prime} \mathrm{N}$ $11^{\circ} 8^{\prime} 34.8^{\prime \prime} \mathrm{E}$ ) in Saxony-Anhalt, Soellingen (SOE, $52^{\circ} 5^{\prime}$ 45.506" N $10^{\circ} 55^{\prime} 41.711^{\prime \prime} \mathrm{E}$ ) and Lenglern (LEN, 51 ${ }^{\circ} 35^{\prime}$ 47.53" N $9^{\circ} 51^{\prime} 39.118^{\prime \prime}$ E) in Lower Saxony. The 394 RILs, the eight founders, and the susceptible standard 'Schamane' 
were evaluated in double rows under natural disease epidemics in SOE (2017 and 2018) and LEN (2018). In QLB entries were sown 2016/2017 and 2017/2018 in double rows of $1 \mathrm{~m}$ length with 30 plants per row and spacing of $0.2 \mathrm{~m}$ between rows. Additional infection stripes of susceptible varieties were arranged in regular intervals of every third plot. Growth regulator Medax ${ }^{\circledR}$ Top (BASF Agricultural Solutions, Germany, $1 \mathrm{~L} \mathrm{ha}^{-1}$ ) was applied twice (BBCH31, $\mathrm{BBCH} 37)$ to reduce plant height and lodging. No selective fungicides were used. To ensure uniform infestation, the infection stripes were artificially inoculated at the beginning of flowering using the highly virulent Puccinia triticina isolate $77 \mathrm{WxR}$ (Tab. S1). For this, a spore suspension of $10 \mathrm{mg}$ uredospores in $100 \mathrm{ml}$ Isopar M (ExxonMobil Chemical Company, USA) was applied in a total amount of $10 \mathrm{ml}$ suspension per $\mathrm{m}^{2}$, using a hand-held spinning disc sprayer (Bromyard, U.K.). Phenotyping of the trials was carried out by scoring the average percentage of infected leaf area of the second and third youngest leaves in the two rows at two (SOE17, SOE18, LEN18), three (QLB18), and four (QLB17) subsequent dates according to Moll et al. (2010), starting at the time of clearly visible disease symptoms on the infection stripe or the susceptible standard, respectively. A time period of 1 to 2 weeks was chosen between the scorings.

\section{Phenotypic assessment of leaf rust resistance in seedlings}

All RILs, the parental lines, and the susceptible standard 'Borenos' were evaluated for resistance at seedling stage in a detached leaf assay (Douchkov et al. 2012). Seedlings were grown in 77-cell trays with mixed potting soil (Gebr. Patzer GmbH Co KG, Sinntal, Germany) using a randomized complete block design with five replications. Water agar $\left(7 \mathrm{~g} \mathrm{~L}^{-1}\right)$ containing $45 \mathrm{mg} \mathrm{L}^{-1}$ benzimidazole (Sigma-Aldrich Chemie GmbH, Taufkirchen, Germany), used to delay senescence of leaf segments, was dispensed in $4 \times 10 \mathrm{~mL}$ aliquots into nonsterile four-well polystyrene plates $(8 \times 12 \times 1 \mathrm{~cm}$, Greiner Bio-One GmbH, Frickenhausen, Germany). Ten days after sowing, when the second leaf was developed, $2.5-\mathrm{cm}$ sections were cut from the middle of the primary leaves and placed into the plates, keeping the randomization. White polytetrafluoroethylene frames (eMachineShop, Mahwah, USA) were used to fix the leaves. Inoculation was performed by an infection tower with three seconds swirling duration and three minutes of settling time (Melching 1967). Due to space restrictions, plates were divided into two infection groups per replication. Each group was inoculated with leaf rust isolate $77 \mathrm{WxR}$ using a mixture of $30 \mathrm{mg}$ uredospores and white clay $(1: 1 \mathrm{w} / \mathrm{w}$, VWR International GmbH, Darmstadt, Germany) after application of a $0.01 \%$ Tween 20 (Sigma-Aldrich) solution to support adhesion. For $24 \mathrm{~h}$, the plates were covered by wet cotton paper to support spore germination in the dark and at high humidity. Inoculated leaf segments were subsequently incubated in greenhouse at night/day temperatures of $16{ }^{\circ} \mathrm{C} / 18{ }^{\circ} \mathrm{C}$ with additional lighting ( $16 \mathrm{~h} / 8 \mathrm{~h}$ day/night) for ten days. Quantitative scoring was conducted using a high-throughput phenotyping platform (Douchkov et al. 2012). Digital images with a resolution of 20 Megapixel and four wavelengths between 315 and $750 \mathrm{~nm}$ (UV, blue, green, and red) were taken automatically from every plate. Subsequently, the leaf area was calculated and compared to the area of uredospore pustules for analyzing the percentage of infected leaf area (Pi) using the software HawkSpex ${ }^{\circledR}$ (Fraunhofer IFF, Magdeburg, Germany). Additionally, all entries were visually evaluated for infection type (IT) using a 0-4 scale (McIntosh et al. 1995). To generate metric data, original IT data were converted to a $0-10$ linear disease scale, modified according to Zhang et al. (2014) as follows: 0,$0 ;,-1,1,+1,-2,2,2+,-3,3,+3$ were coded as $0,0.5$, $1,2,3,4,5,6,7,8$ and 9 , respectively. IT -4 and 4 were coded as 10 and in case of special annotation code " $C$ " for chlorosis, 0.5 was added to the linear scale.

\section{Data analysis}

The multiple scorings of the percentage of infected leaf area in field trials were taken to calculate the area under the disease progress curve (AUDPC) and the average ordinate (AO, Moll et al. 1996) for each RIL using the following equations:

$A U D P C=\sum_{i=1}^{N_{i-1}} \frac{\left(y_{i}+y_{i+1}\right)}{2} *\left(t_{i+1}-t_{i}\right) \quad$ and $\quad A O=\frac{\mathrm{AUDPC}}{\mathrm{T}}$

where $y_{i}$ is the disease level at the ith observation, $t_{i}$ is the time at the ith observation, $N$ is the total number of observations and $T$ is the total observation time from the first to the last scoring date in days. Out of percentage of infected leaf area, AUDPC, and AO, only AO values were used for subsequent statistical analysis. Different year-location combinations of all trials were referred to as "environment".

Analyses of all phenotypic data were carried out using proc mixed of the software package SAS 9.4 (SAS Institute Inc., NY, USA). In order to apply a mixed linear model, a $\log _{10}$ data transformation of the AO, IT, and Pi values was performed. The factors genotype, environment, and the genotype $\times$ environment interaction of field data were set as fix effects, while the design effects of replication and block were set as random. To obtain variance components for calculation of the broad sense heritability, all model parameters were set as random. Heritability was estimated on a progeny mean basis according to Hallauer et al. (2010).

For analyzing IT and Pi scores from seedling test the model: 
$y_{i j k}=\mu+g_{i}+r_{j}+l_{k}\left(r_{j}\right)+e_{i j k}$

was used, where $y_{i j k}$ is the trait observation, $\mu$ is the overall mean, $g_{i}$ is the fixed effect of the genotype, $r_{j}$ is the fixed effect of the replication, $l_{k}$ is the random effect of the infection group nested in the replication and $e_{i j k}$ is the random residual error. Variance components were obtained by fitting the genotype as random to calculate the repeatability as the ratio of the genotypic variance and the sum of the genotypic and the residual error variance divided by the number of replications. For each trait, least-square means (lsmeans) were calculated and used for subsequent QTL analysis.

\section{QTL mapping}

The BMW population and the parental lines were genotyped using the $15 \mathrm{~K}+5 \mathrm{~K}$ Infinium ${ }^{\circledR}$ iSelect ${ }^{\circledR}$ array containing 17,267 single nucleotide polymorphism (SNP) markers (TraitGenetics, Germany). The preparation of genotypic data and the construction of the linkage map used for QTL mapping were described in detail by Stadlmeier et al. (2018). QTL mapping was performed using the $\mathrm{R}(\times 323.2 .5)$ package mpMap V2.0.2 (Huang and George 2011; R Core Team 2017). To conduct simple interval mapping (SIM), founder probabilities were calculated using the function 'mpprob'. These give information about the probability of each locus that the observed genotype was inherited from one of the eight founders and are based on multipoint haplotype probabilities (Broman et al. 2003). To determine the parental origin of an allele, the threshold was set to 0.7. For SIM, a genome-wide significant threshold of $\alpha<0.05$ was calculated for each trait. The thresholds were obtained from permutation of phenotypic data with 1000 simulation runs (Churchill and Doerge 1994). QTL detection was performed using the function 'mpIM', implemented in the mpMap package (Huang and George 2011). Phenotypic variance explained by individual QTL and additive QTL effects were estimated separately using the categorical allele information of the founders. QTL support intervals were determined using the function 'supportinterval' of the mpMap package. A QTL support interval was defined as the map interval surrounding a QTL peak at a $-\log _{10}(p)$ drop of one unit (Huang and George 2011).

In order to compare QTL identified in the present study with previously described QTL, overlapping QTL based on the support interval was merged together. Databases of the Triticeae Toolbox (https://triticeaetoolbox.org/wheat/genot yping/marker_selection.php), GrainGenes (https://wheat .pw.usda.gov/GG3/), as well as CerealsDB (https://www. cerealsdb.uk.net/cerealgenomics/CerealsDB/axiom_downl oad.php) were used to obtain marker information. Physical positions were received by nucleotide BLAST (BLASTn) of the marker sequences against the reference sequence
RefSeq v1.0 using the database of $10+$ Genome Project (https://webblast.ipk-gatersleben.de/wheat_ten_genomes/). BLAST hits were considered significant if the percent identity was greater than $95 \%$, and only the best hit was taken if multiple BLAST hits were detected (Gao et al. 2016). The start and end positions of peak marker sequences preceded by the chromosome name were taken to the URGI database to obtain functional gene annotations available from IWGSC (https://wheat-urgi.versailles.inra.fr/Seq-Repository/Annot ations). Sequences of the closest related species, Triticum urartu (A-genome donor) and Aegilops tauschii (D-genome donor), were considered for the detection of orthologous genes.

\section{Results}

\section{Phenotypic assessment}

Leaf rust severity of field trials clearly varied between years and location, displaying in QLB 2017, SOE 2018, and LEN 2018 the lowest infestations of leaf rust (Fig. S1). Pearson correlation coefficient between the different environments ranged from 0.26 to $0.74(P<0.001)$. Nevertheless, after mixed model adjustment, a broad sense heritability $\left(h^{2}\right)$ of 0.83 was estimated (Table 1). The mean phenotypic distribution of AOs was slightly right-skewed and indicated a broad variability within the population (Fig. 1a), ranging between 0.2 and $34.8 \%$ (mean $13.5 \%$ ) leaf area diseased. However, single maximal AO scores up to $63.8 \%$ were observed within the population (Table 1). The average performance of parental lines was evenly distributed, resulting in a nonsignificant difference $(p<0.05)$ from the progeny mean. Founders 'BAYP4535' and 'Bussard' were identified as the most resistant (4.5\%) and most susceptible (22.9\%) parental line to leaf rust, respectively. The analysis of variance showed significant differences concerning genotype, environment, and the interaction between genotype and environment (Table 2).

Scoring qualitative resistance in seedling test was performed twice- using an image analysis software to obtain the Pi and visually by assessing the IT (1-10). For both traits, phenotypic data revealed a large variability (Fig. 1b and c). The average IT ranged from 0.1 to 9.2 (mean 3.8). For Pi, the disease severity was on average between 0 and 28.3\% (mean $8.5 \%$ ). Phenotypic distributions of IT and Pi were slightly bimodal, with 131 and 185 RILs showing IT values smaller 2 (few areas with restricted sporulation) and Pi values below 5\%, respectively. Maximal scores of 10 (IT) and $57.7 \%(\mathrm{Pi})$ were observed (Table 1). The population means of IT and Pi were not significantly different from the means of parental lines. According to the results of field trials, 'BAYP4535' and 'Ambition' were the most 

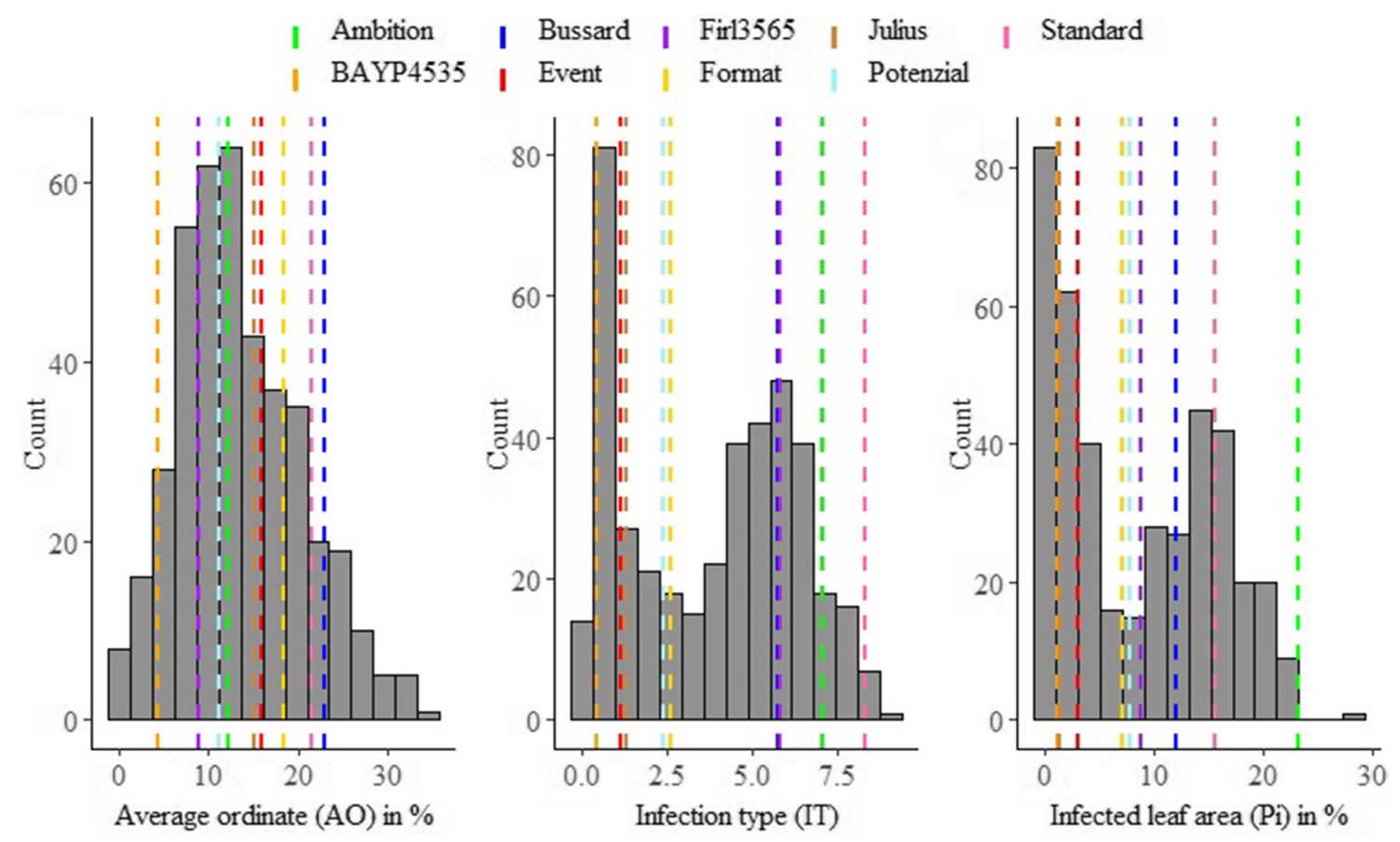

Fig. 1 Averaged phenotypic distribution of resistance to Puccinia triticina for field trials (A) and seedling test (B, C). Performance of each parental line is shown as vertical dashed line

Table 1 Descriptive statistics and heritability / repeatability for field trials $(\mathrm{AO})$ and seedling test (IT and Pi)

\begin{tabular}{lcclllll}
\hline Trait $^{\mathrm{a}}$ & Mean founders & Mean population & $\mathrm{Min}^{\mathrm{b}}$ & $\mathrm{Max}^{\mathrm{c}}$ & $\mathrm{SE}_{ \pm}{ }^{\mathrm{d}}$ & $\mathrm{CV}^{\mathrm{e}}$ & $h^{2} / r e p$ \\
\hline AO [\%] & 13.70 & 13.50 & 0 & 63.75 & 0.17 & 0.83 & $0.83^{\mathrm{f}}$ \\
IT [1-10] & 3.32 & 3.84 & 0 & 10.00 & 0.06 & 0.96 & $0.93^{\mathrm{g}}$ \\
$\mathrm{Pi}[\%]$ & 8.06 & 8.47 & 0 & 57.73 & 0.18 & 0.72 & $0.91^{\mathrm{g}}$ \\
\hline
\end{tabular}

${ }^{\text {a }}$ Average ordinate (AO), infection type (IT), infected leaf area (Pi)

${ }^{\mathrm{b}}$ Minimum

${ }^{c}$ Maximum

${ }^{\mathrm{d}}$ Standard error

${ }^{\mathrm{e}}$ Coefficient of variance

${ }^{\mathrm{f}}$ Broad-sense heritability $\left(h^{2}\right)$

g Repeatability (rep)

resistant and susceptible founders, respectively, in the seedling inoculation test. Pearson correlation displayed a high correlation coefficient between both traits $(r=0.91$; Fig S2 C). The qualitative traits IT and Pi and the quantitative scoring of AO showed weak correlations of $r=0.27$ and $r=0.24$ (Fig S2 A and B). For both traits, a significant genotype effect was observed, while for Pi also a significance of replication was found. Repeatability of both traits was high with $\operatorname{rep}(\mathrm{IT})=0.93$ and $\operatorname{rep}(\mathrm{Pi})=0.91$ (Table 1). From the parental lines, only 'BAYB4535 showed all stage resistance, whereas cv. 'Event', Format', 'Julius', 'Potenzial' only showed resistance at seedling and 'Firl3565' at adult plant stage, respectively. In total, 68 genotypes in the population expressed all stage resistance, 92 genotypes showed resistance only at seedling stage and 44 genotypes were observed showing APR.

\section{QTL mapping}

Overall, SIM revealed 19 QTL located on chromosomes 1A, 4A, 4D, 5A, 6B, 7A, and 7D. Hence, five QTL were detected based on field data and seven QTL for seedling resistance, each for IT and Pi values (Table 3, Tab. S2).

The phenotypic variance $\left(R^{2}\right)$ explained by the individual QTL detected in field trials ranged between 8 and $50 \%$, with support intervals (SI) from 4 to $33 \mathrm{cM}$. The two strongest QTL, explaining $31 \%$ and $50 \%$ of $R^{2}$, were located on chromosome $4 \mathrm{~A}$ with peak markers at $133 \mathrm{cM}$ and $172 \mathrm{cM}$. 
Table 2 Analysis of variance of $\log _{10}$-transformed data for leaf rust severity evaluated in field trials (AO) and seedling test (IT and Pi)

\begin{tabular}{lrrr}
\hline Trait ${ }^{\mathrm{a}} /$ factor & $\mathrm{DF}^{\mathrm{b}}$ & $F$ value & $P$ value \\
\hline AO & & & \\
Genotype & 402 & 18.98 & $<0.0001$ \\
Environment & 4 & 16.05 & 0.0049 \\
Genotype $\times$ environment & 1605 & 2.39 & $<0.0001$ \\
IT & & & \\
Genotype & 402 & 17.69 & $<0.0001$ \\
Replication & 4 & 0.94 & 0.5196 \\
Pi & & & \\
Genotype & 402 & 16.63 & $<0.0001$ \\
Replication & 4 & 6.66 & 0.0426 \\
\hline
\end{tabular}

Significance level at $P<0.05$

${ }^{a}$ Average ordinate (AO), infection type (IT), infected leaf area (Pi)

${ }^{\mathrm{b}}$ Degrees of freedom
The largest allelic effects of these QTL were contributed by 'BAYP4535', reducing disease severity by $3.1 \%$ and $4.0 \%$, respectively. Another QTL detected on chromosome 7D (at $18 \mathrm{cM}$ ) explained $28 \%$ of the phenotypic variance with 'BAYP4535' as the most resistant founder, reducing infected leaf area by $3.2 \%$. Remaining QTL on chromosomes 6B (at $22 \mathrm{cM}$ ) and $7 \mathrm{~A}$ (at $368 \mathrm{cM}$ ) accounted for $8 \%$ and $7 \%$ of leaf rust variation. For these QTL, cv. 'Format' contributed the largest allelic effect reducing infected leaf area by $1.3 \%$ and $1.4 \%$, respectively.

For IT, phenotypic variance explained by the seven QTL ranged from 1 to $28 \%$ with SIs ranging between 2 and $53 \mathrm{cM}$ (Table 3). QTL on chromosomes 4A and 7D accounted for the highest $R^{2}$ i.e. $28 \%$ and $17 \%$ with peak markers at $170 \mathrm{cM}$ and $22 \mathrm{cM}$. The largest allelic effect of both QTL was contributed by 'BAYP4535', reducing disease severity by 2.6 and 1.8 scores, respectively. On chromosome $1 \mathrm{~A}$, one QTL was detected at $28 \mathrm{cM}$, explaining $11 \%$ of the phenotypic variance. A maximum effect of -1.0 score was detected for cv. 'Potenzial'. Furthermore, two QTL were detected on chromosome 5A with $8 \%$ (at $112 \mathrm{cM}$ ) and $7 \%$ (at $139 \mathrm{cM}$ )

Table 3 QTL for resistance to Puccinia triticina in the BMW population detected in field trials and seedling tests

\begin{tabular}{|c|c|c|c|c|c|c|c|c|c|c|c|c|c|c|}
\hline Trait & Chr. $^{a}$ & Pos. $[\mathrm{cM}]^{\mathrm{b}}$ & $\mathrm{SI}[\mathrm{cM}]^{\mathrm{c}}$ & $P$ value & $R^{2 \mathrm{~d}}$ & No. Env. ${ }^{\mathrm{f}}$ & Eff $(A)^{g}$ & Eff $(B)^{g}$ & Eff $(C)^{g}$ & Eff $(D)^{\mathrm{g}}$ & Eff $(E)^{g}$ & Eff $(F)^{g}$ & Eff $G)^{g}$ & Eff $(H)^{g}$ \\
\hline \multirow[t]{5}{*}{ AO } & $4 \mathrm{~A}$ & 133 & $125-151$ & $2.00 \mathrm{E}-22$ & 0.31 & & -0.17 & -3.12 & +0.93 & -1.21 & +0.90 & +0.88 & +0.86 & $+0,83$ \\
\hline & $4 \mathrm{~A}$ & 172 & $170-174$ & $2.52 \mathrm{E}-58$ & 0.50 & 4 & +0.94 & -3.96 & -0.13 & -0.44 & +2.04 & -0.18 & +1.94 & $-0,23$ \\
\hline & $6 \mathrm{~B}$ & 22 & $10-30$ & $1.49 \mathrm{E}-05$ & 0.08 & 1 & +0.16 & -1.23 & +1.70 & +1.25 & -1.32 & -0.89 & -1.16 & +1.47 \\
\hline & $7 \mathrm{~A}$ & 368 & $346-379$ & $1.52 \mathrm{E}-05$ & 0.07 & 1 & -0.16 & -1.26 & +1.10 & -1.39 & -1.42 & +1.22 & +0.94 & +0.89 \\
\hline & $7 \mathrm{D}$ & 18 & $15-19$ & $3.68 \mathrm{E}-32$ & 0.28 & 4 & na & -3.16 & na & na & +1.44 & +0.94 & +0.18 & +0.58 \\
\hline \multirow[t]{7}{*}{ IT } & $1 \mathrm{~A}$ & 28 & $0-34$ & $1.55 \mathrm{E}-06$ & 0.11 & & na & +0.76 & -0.27 & na & -0.75 & -0.98 & -0.67 & +1.88 \\
\hline & $4 \mathrm{~A}$ & 170 & $168-174$ & $8.79 \mathrm{E}-23$ & 0.28 & & 0.00 & -2.57 & -1.32 & +1.59 & +1.15 & -1.10 & +1.58 & +1.12 \\
\hline & $4 \mathrm{D}$ & 69 & $59-86$ & $2.57 \mathrm{E}-05$ & 0.01 & & na & +0.01 & na & na & +1.16 & na & na & -1.98 \\
\hline & $5 \mathrm{~A}$ & 112 & $102-152$ & $1.56 \mathrm{E}-05$ & 0.08 & & -0.99 & +0.21 & +0.63 & +0.06 & -2.06 & +0.67 & +0.87 & +0.60 \\
\hline & $5 \mathrm{~A}$ & 139 & 99-152 & $3.31 \mathrm{E}-05$ & 0.05 & & -0.26 & +0.78 & +1.29 & -1.29 & -1.44 & +1.12 & -1.29 & +1.07 \\
\hline & $6 \mathrm{~B}$ & 249 & $248-250$ & $2.18 \mathrm{E}-55$ & 0.01 & & -0.5 & na & na & na & na & na & na & +0.5 \\
\hline & $7 \mathrm{D}$ & 22 & $15-30$ & $6.14 \mathrm{E}-12$ & 0.17 & & na & -1.84 & na & na & +0.61 & +0.61 & +0.02 & +0.61 \\
\hline \multirow[t]{7}{*}{$\mathbf{P i}$} & $1 \mathrm{~A}$ & 26 & $0-34$ & $8.11 \mathrm{E}-06$ & 0.12 & & na & +0.60 & +1.64 & na & -1.35 & -1.59 & -1.27 & +1.98 \\
\hline & $4 \mathrm{~A}$ & 171 & $168-174$ & $1.11 \mathrm{E}-16$ & 0.21 & & +0.33 & -4.14 & -1.33 & +1.67 & +1.47 & -0.88 & +1.47 & +1.42 \\
\hline & $4 \mathrm{D}$ & 72 & $59-86$ & $4.27 \mathrm{E}-06$ & 0.09 & & na & -0.06 & na & na & +1.6 & na & na & -1.54 \\
\hline & $6 \mathrm{~B}$ & 249 & $247-250$ & $1.76 \mathrm{E}-91$ & $<.01$ & & -0.52 & na & na & na & na & na & na & +0.53 \\
\hline & $7 \mathrm{~A}$ & 65 & $54-87$ & 7.02E-06 & 0.05 & & na & +1.05 & +2.15 & -0.95 & -0.13 & -0.73 & -1.41 & +0.03 \\
\hline & $7 \mathrm{~A}$ & 99 & 94-111 & $6.12 \mathrm{E}-06$ & 0.08 & & -0.97 & +1.38 & +0.81 & +0.08 & +0.21 & +0.23 & -2.38 & +0.65 \\
\hline & $7 \mathrm{D}$ & 22 & $15-30$ & 5.64E-09 & 0.14 & & na & -2.78 & na & na & +1.11 & +1.11 & -0.27 & +0.85 \\
\hline
\end{tabular}

${ }^{\text {a }}$ Chromosomal position of QTL

${ }^{\mathrm{b}}$ Position of peak marker based on Stadlmeier et al. (2018)

${ }^{c}$ Support interval

${ }^{\mathrm{d}}$ Proportion of phenotypic variance explained by a single QTL

${ }^{\mathrm{f}}$ Number of single environments in which QTL was detected

${ }^{g}$ Additive effects $( \pm)$ of the founders Event (A), BAYP4535 (B), Ambition (C), Firl3565 (D), Format (E), Potenzial (F), Bussard (G) and Julius (H) relative to the population mean. Shown values are back-transformed to the original trait scale

Founder effects were reported as not available (na) if none of the RILs reached the probability threshold of 0.7 
of the explained variance. SIs of these QTL ranged from 102 to $152 \mathrm{cM}$ and from 99 to $152 \mathrm{cM}$, respectively. For both, 'Format' contributed the highest allelic effect $(-2.1$ and - 1.4 scores). QTL located on chromosomes 4D (69 cM) and $6 \mathrm{~B}(249 \mathrm{cM})$ explained only $1 \%$ of the phenotypic variance, each. By analyzing each environment separately, the two QTL on chromosomes 4A were also detected in LEN18, QLB17, QLB18 and SOE18, as well as LEN18, QLB18, SOE17 and SOE18, respectively. The QTL on chromosome 6B and 7D was detected in one (SOE18) and four (LEN18, QLB17, QLB18, SOE18) environments.

SIM of Pi values also revealed seven individual QTL with $R^{2}$ ranging from less than $1 \%$ to $21 \%$. The support intervals varied between 2 and $34 \mathrm{cM}$. QTL regions on chromosomes 1A, 4A, 4D, 6B and 7D overlapped with QTL regions detected for IT (Table 3). Nevertheless, smaller $R^{2}$ of $21 \%$ (4A), $14 \%$ (7D) and $<1 \%(6 \mathrm{~B})$, as well as larger $R^{2}$ of $12 \%$ (1A) and 9\% (4D) were calculated for individual QTL. The maximal reducing effect of the QTL on chromosomes $1 \mathrm{~A}$, $4 \mathrm{~A}, 4 \mathrm{D}$, and $6 \mathrm{~B}$ ranged between $0.5 \%$ and $4.1 \%$, while for $7 \mathrm{D}$, only the founder 'BAYP4535' showed a reducing allelic effect of $2.8 \%$. Additionally, two QTL were detected on chromosome 7A at $65 \mathrm{cM}$ and $99 \mathrm{cM}$, accounting for $5 \%$ and $8 \%$ of the phenotypic variance. SI ranged from 54 to $87 \mathrm{cM}$ and from 94 to $111 \mathrm{cM}$, respectively. Founders 'Firl3565' and 'Bussard' contributed the largest allelic effect, reducing the disease severity by $0.9 \%$ and $2.4 \%$.

Based on support intervals of 19 QTL, detected in total for the different traits, 11 main QTL were identified (Fig. S3, Table 4). In silico annotations of peak markers revealed seven genes with known functions partly involved in resistance. Hence, marker CAP8_c2448_355 on chromosome 1A referred to a DnaJ domain. A Protein kinase domain and a NB-ARC domain were identified for peak markers of $Q L r$. jki-4A.1 and $Q L$ r.jki-4A.2 on chromosome 4A. Marker $A X$ 95126745 on chromosome 4D and RAC875_c31670_389 on chromosome $5 \mathrm{~A}$ referred to a cation/calcium exchanger 4 and ankyrin repeats, respectively. For peak markers of $Q L r$. jki-7A.l and QLr.jki-7A.l on chromosome 7A, a pyridoxalphosphate dependent enzyme and a sugar efflux transporter were annotated, respectively.

\section{Discussion}

Continuous evolution of leaf rust results in the emergence of new pathotypes virulent against single major resistance genes commonly present in cultivars. Many of these race specific $L r$ genes have been broken down in the past (Kolmer 2005; Serfling et al. 2013). Detection of effective leaf rust resistances is of essential importance to avoid rust epidemics. Therefore, experimental populations such as MAGIC populations provide powerful tools to discover, characterize, and deploy QTL for complex traits including resistances (Cavanagh et al. 2008). Out of 80 designated $L r$ genes, it was reported, that only $\operatorname{Lrl}, \operatorname{Lr} 3, \operatorname{Lr} 10, \operatorname{Lr} 13, \operatorname{Lr} 14 a, L r 17 b$, $L r 20, L r 24, L r 26, L r 34$, and $L r 37$ were used individually or in combination in European varieties (Goyeau et al. 2006; Goyeau and Lannou 2011; Serfling et al. 2013). The BMW population emerged from crosses of eight elite parental lines originating from Germany and Denmark. Nevertheless, Stadlmeier et al. (2018) were able to show the potential of the BMW population to detect new QTL for resistance to powdery mildew, septoria tritici blotch, as well as tan spot, and in general the usefulness for further gene mapping studies (Stadlmeier et al. 2018, 2019).

In this study, phenotyping of 394 RILs from the BMW population resulted in a broad variability of resistance to Puccinia triticina. Despite an average correlation coefficient of 0.54 between the disease severities in five environments, a broad sense heritability of 0.83 was calculated which is in the range of previously published studies (Bemister et al. 2019; Gao et al. 2016; Zhang et al. 2017, 2019). This may hint to a quantitative inheritance due to QTL involved in slow rusting loci, which are characterized by relatively high heritabilities (Kolmer 1996). Phenotypic distribution for field trials was slightly right-skewed, while almost a bimodal distribution was observed for both IT and Pi values in seedling test. This may give hint that mostly horizontal (quantitative) or vertical (qualitative) resistances were scored, respectively. Calculation of correlation between field data and seedling test results showed $r$ values of 0.27 (IT) and $0.24(\mathrm{Pi})$, which are in accordance with correlations reported by Gao et al. (2016). Different virulence/ avirulence patterns of leaf rust races may be an explanation for these low correlations (Gao et al. 2016). While a single highly aggressive race, with many virulence genes was used for artificial inoculation for seedling tests and field trials in QLB, field trials in SOE and LEN were conducted under natural infection pressure.

Overall, simple interval mapping detected 19 QTL, which corresponded to 11 distinct chromosomal regions (Table 4, Fig. S3). QTLs identified using the LSmeans over all environments were also identified by analyzing the single environments separately. Out of the 11 distinct chromosomal regions three QTL were detected at the adult plant stage. Six QTL conferred seedling resistance and two were active in both growth stages, indicating the presence of effective all-stage leaf rust resistance genes. In total, the regions were located on wheat chromosomes 1A, 4A, 4D, 5A, 6B, 7A and 7D. Peak markers of QTL could be partially annotated to genes, known to be involved in quantitative resistances to leaf rust, e.g. sugar efflux transporters, DnaJ domain belonging to heat shock protein family (Bekh-Ochir et al. 2013), a protein kinase domain, a NBARC domain and a cation/calcium exchanger. Such genes 


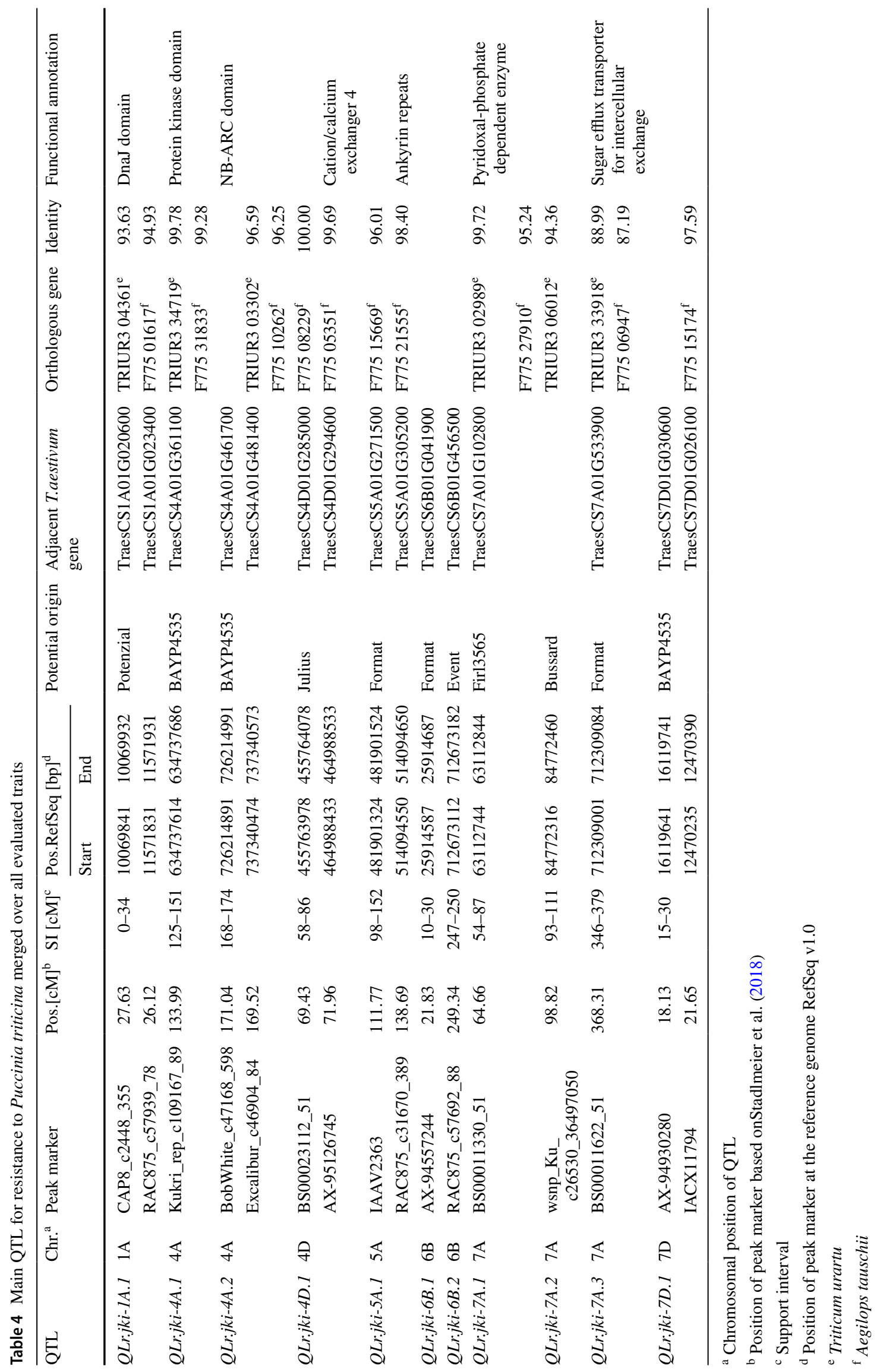


show an increased expression during defense reactions in wheat-leaf rust (Sharma et al. 2018) and wheat-stripe rust interactions (Wang et al. 2020) and as response to environmental stresses.
In this study, QLr.jki-1A.1 on chromosome $1 \mathrm{~A}$ is based on the evaluation of IT and Pi in seedling tests and is physically located in a region between 1.3 Mbp and 12.5 Mbp (Table 5). Pinto da Silva et al. (2018) reviewed 11 QTL

Table 5 Comparison of physical positions of the QTL identified in the present study (bold) with those reported previously. Physical positions based on comparison of marker sequence data to the wheat reference genome (RefSeq1.0)

\begin{tabular}{|c|c|c|c|c|}
\hline QTL & Marker interval & Physical position [Mbp] & Genetic material & References \\
\hline$Q L r . j k i-1 A .1$ & $\begin{array}{l}\text { IAAV3919-Tdurum_con- } \\
\text { tig42479_3800 }\end{array}$ & $1.3-12.5$ & BMW population $\left(\mathrm{RIL}^{\mathrm{a}}\right)$ & Lr10? \\
\hline QLr.ccsu-1A.1 & Xbarc263-Xcdo426 & $11.8-\mathrm{na}^{\mathrm{b}}$ & Opata85×W-7984 (RIL) & Kumar et al. (2013) \\
\hline QLr.cau-1AS & gpw2246 & 7.7 & Luke×AQ24788-83 (RIL) & Du et al. (2015) \\
\hline$M T A$ & IWA3182-IWA7191 & $7.1-13.7$ & Spring wheat collection & Elbasyoni et al. (2017) \\
\hline $\operatorname{Lr} 10$ & & 12.6 & & Feuillet et al. (2003) \\
\hline$Q L r . j k i-4 A .1$ & AX-95253498-TA006348.0950 & $618.6-649.9$ & BMW population (RIL) & \\
\hline$M T A$ & IWA2816 & 641.5 & Hexaploid Wheat Landraces & Kertho et al. (2015) \\
\hline$Q L r . j k i-4 A .2$ & $\begin{array}{l}\text { Tdurum_contig75819_1220- } \\
\text { Excalibur_c33542_113 }\end{array}$ & 712.9-na & BMW Population (RIL) & \\
\hline $4 A \_t 2$ & BobWhite_c47168_289 & 726.2 & Elite spring wheat lines & Gao et al. (2016) \\
\hline QLr.hebau- $4 A L$ & $\begin{array}{l}\text { BobWhite_c15697_675-Excali- } \\
\text { bur_c2827_580 }\end{array}$ & $598.7-726.4$ & $\begin{array}{l}\text { Zhou8425B } \times \text { Chinese Spring } \\
\text { (RIL) }\end{array}$ & Zhang et al. (2017) \\
\hline$Q L r . j k i-4 D .1$ & AX-94793903-AX-94838884 & $130.9-479.7$ & BMW population (RIL) & Novel? \\
\hline$Q L r . f c u-4 D L$ & Xgdm61-Xcfa2173 & na & TA4152-60×ND495 $\left(\mathrm{DH}^{\mathrm{c}}\right)$ & Chu et al. (2009) \\
\hline QLr.hebau-4DL & AX-110476142-AX-111092299 & $381.2-428.6$ & Pingyuan $50 \times$ Mingxian 169 & Zhang et al. (2019) \\
\hline QLr.sfrs- $4 D L$ & Xglk302b-Xpsr1101a & na & Forno $\times$ Oberkulmer (RIL) & Messmer et al. (2000) \\
\hline Lr67 & Xgwm165-Xgwm192 & 412.7 & RL6077×Avocet (RIL) & Herrera-Foessel et al. (2011) \\
\hline$Q L r . j k i-5 A .1$ & $\begin{array}{l}\text { AX-94732470-wsnp_Ex_E } \\
\text { c49211_53875600 }\end{array}$ & 444.6-na & BMW population & Novel? \\
\hline QLr.cim-5AC & wPt-3187-wPt-7769 & $\mathrm{Na}-464.7$ & $\begin{array}{l}\text { Avocet-YrA } \times \text { Kenya Kongoni } \\
\text { (RIL) }\end{array}$ & Calvo-Salazar et al. (2015) \\
\hline$Q L r . j k i-6 B .1$ & AX-94739546-TA003005.0339 & $19.3-34.3$ & BMW population & Novel? \\
\hline QLr.caas-6BS.1 & Xcfd13-Xwmc487 & $34.2-36.5$ & Bainong64×Jingshuang16 (DH) & Ren et al. (2012) \\
\hline QLr.wpt-6BS.2 & wPt2175 & $\mathrm{na}^{\mathrm{b}}$ & Winter wheat accessions & Gerard et al. (2018) \\
\hline$Q L r . j k i-6 B .2$ & $\begin{array}{l}\text { wsnp_Ex_c54772_57528275- } \\
\text { Excalibur_c29748_954 }\end{array}$ & $710.1-719.7$ & BMW population & $\operatorname{Lr} 3 ?$ \\
\hline QLr.cim-6BL & $277,143-1,234,305$ & 714.3-na & Bairds $\times$ Atred\#1 (RIL) & Lan et al. (2017) \\
\hline $6 B \_4$ & $\begin{array}{l}\text { BobWhite_c43263_180- } \\
\text { BS00011795_51 }\end{array}$ & $718.9-720.6$ & Elite spring wheat lines & Gao et al. (2016) \\
\hline$Q L r . j k i-7 A .1$ & $\begin{array}{l}\text { BobWhite_rep_c58252_112- } \\
\text { wsnp_BF473884A_Ta_1_3 }\end{array}$ & $54.9-71.1$ & BMW population & Novel \\
\hline$Q L r . j k i-7 A .2$ & $\begin{array}{l}\text { RAC875_c75528_355- } \\
\text { BS00024786_51 }\end{array}$ & 79.6-na & BMW population & Novel? \\
\hline QLr.stars-7AS1 & wsnp_Ex_c41150_48040078 & 78.4 & Winter wheat accessions & Li et al. (2016) \\
\hline MTA & IWA7192 & 81.1 & Spring wheat collection & Elbasyoni et al. (2017) \\
\hline Lr47 & & 115 & & Helguera et al. (2000) \\
\hline$Q L r . j k i-7 A .3$ & $\begin{array}{l}\text { Tdurum_contig29240_206- } \\
\text { wsnp_CAP11_c298_250917 }\end{array}$ & $702.4-724.1$ & BMW Population & $\operatorname{Lr} 20 ?$ \\
\hline MTA & IWA4175 & 717.1 & Spring wheat accessions & Turner et al. 2017 \\
\hline QLr.jki-7D.1 & TA016282.1180-AX-94883448 & na-29.4 & BMW Population & Novel \\
\hline Lr34 & & $47.4-51$ & & Krattinger et al. (2009) \\
\hline
\end{tabular}

${ }^{a}$ Recombinant inbred line population

${ }^{\mathrm{b}}$ marker information was not available or position could not be identified in the RefSeq v1.0

${ }^{\mathrm{c}}$ Doubled haploid population 
described in hexaploid wheat located on chromosome 1A. Based on available physical marker positions, QLr.ccsu$1 A .1$ and $Q L$ r.cau- $1 A S$ identified in two different studies, were found to correspond to the region of QLr.jki-1A.l (Du et al. 2015; Kumar et al. 2013). While QLr.ccsu-1A.l is only $1.7 \mathrm{Mbp}$ and $0.2 \mathrm{Mbp}$ apart from our peak markers, the distance of the linked marker to QLr.cau- $1 A S$ is $2.4 \mathrm{Mbp}$ and 3.9 Mbp, respectively (Tables 4, 5). Additionally, Elbasyoni et al. (2017) detected several marker-trait associations (MTAs) covering a region from 7.2 Mbp to 13.7 Mbp, which includes the region of $Q L r . j k i-1 A$.1. Furthermore, the resistance gene $L r 10$, which is completely sequenced, is mapped at $12.6 \mathrm{Mbp}$, i.e. $2.5 \mathrm{Mbp}$ and $1 \mathrm{Mbp}$ apart from our peak marker (Table 4; Feuillet et al. 1997, 2003). Thus, and due to the fact that $L r 10, L r 1, L r 3 a$ and $L r 20$ are the most prevalent genes used worldwide, $\operatorname{Lr} 10$ is a promising candidate for the QTL aforementioned (Dakouri et al. 2013).

On chromosome 4A, two regions harboring leaf rust resistance were identified in this study (QLr.jki-4A.1, $Q L r$. $j k i-4 A .2$, Table 4). To date, there are two $L r$ genes, $L r 28$ originating from Ae. speltoides and Lr30 from T. aestivum, and two QTL reported on chromosome 4A (Dyck and Kerber 1971; McIntosh et al. 2013; Pinto da Silva et al. 2018). Kertho et al. (2015) found one MTA at 641.5 Mbp, using the leaf rust race MCDL. Therefore, the marker is physically located within the region of $Q L r . j k i-4 A .1$, but $6.8 \mathrm{Mbp}$ apart from our peak marker. Due to the specific virulence pattern of the MCDL race, which is avirulent to Lr30, the MCDLMTA might identify this $L r$ gene. However, to our knowledge, no mapping information for $L r 30$ is available to allow a more precise comparison between $L r 30$, the MCDL-MTA and $Q L r . j k i-4 A .1$ detected in this study. Another significant MTA (4A_t2, Gao et al. 2016) was detected in the region of $Q L r . j k i-4 A .2$, only 309 bp apart from the peak marker for this QTL (Table 4). 4A_t2 was mapped approximately at the position of the marker linked to $\operatorname{Lr} 28$ (Bipinraj et al. 2011). This may be a hint that $Q L r . j k i-4 A .2$ also corresponds to $L r 28$, but further analyses have to be conducted. Furthermore, Zhang et al. (2017) reported a minor QTL for APR in Chinese Spring (QLr.hebau-4AL), which is physically located between 598.7 Mbp and 726.4 Mbp. This region includes both QTL on chromosome 4A detected in this study (Table 5).

In total, nine QTLs were detected on chromosome $4 \mathrm{D}$ so far, including the resistance gene $\mathrm{Lr67/Yr46/Sr} 55$ (HerreraFoessel et al. 2011; McIntosh et al. 2013; Pinto da Silva et al. 2018). In this study, QLr.jki-4D.1 was detected for both IT and $\mathrm{Pi}$ in the seedling tests and mapped at the distal end of chromosome 4DL. Physically, it is located in a large interval from 130.9 Mbp to 479.7 Mbp (Table 5) with peak markers at $455.8 \mathrm{Mbp}$ and $465 \mathrm{Mbp}$, respectively (Table 4). Chu et al. (2009) located a QTL ( $Q L r . f c u-4 D L)$ in douple-haploid population 'TA4152-60 $\times$ ND495', mapped at a similar position as $\mathrm{Lr67}$, around $412.7 \mathrm{Mbp}$ (Herrera-Foessel et al. 2011; Zhang et al. 2019). Another QTL on chromosome 4DL (QLr.hebau-4D) was located between 381.2 Mbp and 428.6 Mbp (Zhang et al. 2019). Considering the physical distances to our peak marker, it appears that $Q L r . j k i-4 D .1$ is independent from QLr.fcu-4DL, QLr.hebau- $4 D$, and $L r 67$ (Table 5). A higher similarity may exist with another QTL (QLr.sfrs-4DL) detected by Messmer et al. (2000). This QTL resulted in an APR and was mapped in the Swiss RIL population 'Forno $\times$ Oberkulmer' also at the distal end of chromosome 4DL. Since $Q L$ r.jki-4D. 1 has only been detected at the seedling stage, QLr.sfrs-4DL also seems to be located in a different region and with the available data, it is not possible to further determine whether it corresponds to our regions.

On chromosome 5A one QTL (QLr.jki-5A.1) was detected in seedling tests for IT (Table 4). To our knowledge, on chromosome 5A there is no designated $L r$ gene and only two QTL (QLr.cim-5AC, QLr.cimmyt-5A) are known (CalvoSalazar et al. 2015; Rosewarne et al. 2012). QLr.cimmyt-5A was mapped on the long arm of chromosome $5 \mathrm{~A}$, closely linked to $V r n-A l$ at $587.0 \mathrm{Mbp}$ (Rosewarne et al. 2012). QLr. cim-5AC was located in the centromeric region of chromosome 5A and flanked by markers $w P t-7769$ and $w P t-3187$, of which the latter is located at $464.7 \mathrm{Mbp}$ (Table 5). When comparing the physical positions of these three QTL, it is more likely that $Q L r . j k i-5 A .1$ corresponds to QLr.cim-5AC or is a novel QTL.

On chromosome 6B, two QTL were identified ( $Q L r . j k i$ $6 B .1$ and $Q L r . j k i-6 B .2$ ) in the present study (Table 4). $Q L r$. $j k i-6 B .1$ was mapped on the short arm of chromosome 6B, at 19.3-34.3 Mbp (Table 5). Up to now, 5 QTL have been described on chromosome 6BS, but only QLr.caas-6BS.1, derived from the wheat cultivar Bainong 64 , was physically localized in the region between 32 and $34 \mathrm{Mbp}$ (Gerard et al. 2018; Kankwatsa et al. 2017; Ren et al. 2012). Gerard et al. (2018) stated that another QTL (QLr.wpt-6BS.2) is genetically located in the same region as QLr.caas 6BS.1, whereas QLr.wpt-6BS.2 was mapped close to the centromere, a region clearly distinct from $Q L$ r.jki-6B.l (Table 5). Therefore, further studies are required to confirm whether our QTL is located closely to these known QTL. The second QTL QLr.jki-6B.2 was mapped at the distal end of chromosome 6BL, within a small interval encompassing $247 \mathrm{cM}$ to $250 \mathrm{cM}(710-720 \mathrm{Mbp})$. Out of six QTL already detected on chromosome 6BL, two QTL (QLr.cim-6BL and 6B_4) were also located at the distal end of chromosome 6BL (Chu et al. 2009; Gao et al. 2016; Lan et al. 2017; Rosewarne et al. 2012; William et al. 2006). The DArTseq markers 1234305 and 2277143 flank QLr.cim-6BL detected by Lan et al. (2017). Marker 2277143 was converted into a diagnostic KASP marker, which is located at $714.3 \mathrm{Mbp}$, i.e. 1.6 Mbp distal from our peak marker of QLr.jki-6B.2 (Tables 4, 5 ). The results of Lan et al. (2017) indicated uniqueness of $Q L r$. 
cim-6BL, showing no relationship to other QTL on chromosome 6BL, as well as to $\mathrm{Lr3a}$ co-segregating with $\mathrm{Xmwg} 798$ (Sacco et al. 1998). However, the second known QTL 6B_4 was physically mapped between $718.9 \mathrm{Mbp}$ and $720.6 \mathrm{Mbp}$, and appeared to be in high linkage disequilibrium with $\mathrm{Lr} 3$ (Gao et al. 2016). Regarding the similar physical regions, $Q L r . j k i-6 B .2$ may correspond to $Q L r . c i m-6 B L$ and $6 B \_4$, but further research is needed to come to a closer understanding of the relationship between these QTL and $L r 3$.

On chromosome 7A, the major resistance genes $L r 20$, forming a disease-resistance gene cluster with $P m l$, and $\mathrm{Lr} 47$, which was transferred from chromosome $7 \mathrm{~S}$ of Ae. speltoides have been reported (Dubcovsky et al. 1998; Neu et al. 2002). Additionally, three QTL on chromosome 7AL and several MTAs were detected (Pinto da Silva et al. 2018). In the present study, three QTL (QLr.jki-7A.I to $Q L r . j k i-7 A .3)$ were identified on chromosome 7A. The first two QTL were detected for Pi in the seedling test and their support intervals were separated from each other by a map distance of $7.1 \mathrm{cM}$ on chromosome 7AS. QLr.jki-7A.1 was physically mapped between $54.9 \mathrm{Mbp}$ and $71.1 \mathrm{Mbp}$ (Table 5). To our knowledge, no QTL have been reported in this region. Hence, QLr.jki-7A.1 might be a novel QTL. The second QTL (QLr.jki-7A.2) on chromosome 7AS was located between 93 and $111 \mathrm{cM}$. The peak marker was mapped at $84.8 \mathrm{Mbp}$ (Table 4). To date, there are two MTAs from different studies detected in similar regions as $Q L r$. jki-7A.2 (Elbasyoni et al. 2017; Li et al. 2016). The first MTA (QLr.stars-7AS1), associated with marker IWA3760 was mapped at $78.4 \mathrm{Mbp}$, hence, it appears that QLr.stars$7 A S 1$ does not correspond to QLr.jki-7A.2. The second MTA (IWA7192) was detected by Elbasyoni et al. (2017) at 81.1 Mbp, and might be correspondent to the resistance gene Lr47. When comparing the physical position of a diagnostic marker for $L r 47$ (around $115 \mathrm{Mbp}$ ), both IWA7192, and QLr.jki-7A.2 seem to be different from this $L r$ gene (Helguera et al. 2000). Thus, $Q L r . j k i-7 A .2$ is likely a novel locus involved in resistance to $P$. triticina.

The third QTL ( $Q L r . j k i-7 A .3)$ determined in field trials during this study was mapped between 346 and $379 \mathrm{cM}$ on chromosome 7AL. This translates to a large physical distance between 702.4 Mbp and 724.1 Mbp, with the peak marker at 712.3 Mbp (Tables 4, 5). Out of five known regions on chromosome 7AL involved in leaf rust resistance (Kankwatsa et al. 2017; Li et al. 2016; Lu et al. 2017; Tsilo et al. 2014), only the MTA detected by Turner et al. (2017) may be localized within the region of $Q L r$. $j k i-7 A .3$. The associated marker IWA4175 was mapped at $717.1 \mathrm{Mbp}$, which is $4.8 \mathrm{Mbp}$ apart from our peak marker. However, after Bonferroni correction, the marker was no longer significant $(P<0.1)$. The $L r$ gene $L r 20$ is genetically located in the distal part of chromosome 7AL (Neu et al. 2002), which may correspond to QLr.jki-7A.3. Based on the available data, investigations with diagnostic markers need to be conducted to gain further insights.

Finally, one QTL was detected on chromosome 7DS, based on phenotypic data from field trials and seedling test (Table 4). To date, out of 21 QTL reported on chromosome 7D, 19 correspond to the resistance gene Lr34, which confers race non-specific, partial, and slow rusting resistance to leaf rust (Lagudah et al. 2009; Pinto da Silva et al. 2018). Lr34 has been physically located at 47.4 Mbp (Krattinger et al. 2009). Thus, QLr.jki-7D.1 identified in our study does not correspond to the resistance gene $\operatorname{Lr} 34$ and the 19 QTL reported (Table 5). The remaining two QTL QLr.cim-7DS and QLr.hebau-7DS on chromosome 7DS, which were detected in the two RIL populations 'Avocet-YrA $\times$ Francolin\#1' and 'Shanghai3/ Catbird $\times$ Naxos', respectively, were located in different chromosome region (Lan et al. 2014; Zhou et al. 2014). Hence, QLr.jki-7D.1 seems to be a novel locus.

The objective of this study was to identify QTL for resistance to leaf rust, using the Bavarian MAGIC Wheat population. We identified 19 leaf rust resistance QTL that were confined to 11 distinct chromosomal regions. To date, more than 249 leaf rust resistance QTL and 200 MTAs were reported covering all 21 chromosomes of hexaploid wheat (Pinto da Silva et al. 2018). These regions were identified in several mapping populations using different genotyping methods. Because of the absence of information on physical positions for many of these QTL, it is difficult to unequivocally determine the identity of newly described QTL. In the present study, six putatively new QTL were identified on chromosomes 4D, 5A, 6B, 7A and 7D. SNP markers linked to these regions may be converted into KASP markers suitable for MAS in wheat breeding programs (Neelam et al. 2013; Rasheed et al. 2016). This will enable stacking of the detected resistance loci to breed new varieties with an improved resistance to leaf rust.

Acknowledgement This research was supported by the Federal Ministry for Food and Agriculture (BMEL) (FKZ 2818200515). The authors deeply thank all project partners from Strube Research and Breun Saatzucht for conducting and scoring the field trials in Söllingen and Lenglern. We also gratefully thank Melanie Stadlmeier for providing the genotypic data and the genetic map of the BMWpop, as well as for helpful advice on the use of 'mpMap' package. The authors thank NIAB for provision of MAGIC analysis script.

Author contributions statement LH and FO planned and managed the project. LH and MG provided and characterized all RILs. MG contributed in the analyses of the results. AS, FO, MG, LH, and VM contributed to the interpretation and discussion of the results. SR conducted the field screenings and seedling test, analyzed the data and wrote the manuscript.

Funding Open Access funding provided by Projekt DEAL. 


\section{Compliance with ethical standards}

Conflict of interest The authors declare that there are no conflicts of interest in the reported research.

Open Access This article is licensed under a Creative Commons Attribution 4.0 International License, which permits use, sharing, adaptation, distribution and reproduction in any medium or format, as long as you give appropriate credit to the original author(s) and the source, provide a link to the Creative Commons licence, and indicate if changes were made. The images or other third party material in this article are included in the article's Creative Commons licence, unless indicated otherwise in a credit line to the material. If material is not included in the article's Creative Commons licence and your intended use is not permitted by statutory regulation or exceeds the permitted use, you will need to obtain permission directly from the copyright holder. To view a copy of this licence, visit http://creativecommons.org/licenses/by/4.0/.

\section{References}

Aktar-Uz-Zaman M, Tuhina-Khatun M, Hanafi MM, Sahebi M (2017) Genetic analysis of rust resistance genes in global wheat cultivars: an overview. Biotechnol Biotechnol Equip. https://doi. org/10.1080/13102818.2017.1304180

Asimit J, Zeggini E (2010) Rare variant association analysis methods for complex traits. Annu Rev Genet. https://doi.org/10.1146/annur ev-genet-102209-163421

Bandillo N, Raghavan C, Muyco PA, Sevilla MAL, Lobina IT, DillaErmita CJ, Tung C-W, McCouch S, Thomson M, Mauleon R, Singh RK, Gregorio G, Redoña E, Leung H (2013) Multi-parent advanced generation inter-cross (MAGIC) populations in rice: progress and potential for genetics research and breeding. Rice (N Y). https://doi.org/10.1186/1939-8433-6-11

Bayer MM, Rapazote-Flores P, Ganal M, Hedley PE, Macaulay M, Plieske J, Ramsay L, Russell J, Shaw PD, Thomas W, Waugh R (2017) Development and evaluation of a barley 50k iSelect SNP array. Front Plant Sci. https://doi.org/10.3389/fpls.2017.01792

Bekh-Ochir D, Shimada S, Yamagami A, Kanda S, Ogawa K, Nakazawa M, Matsui M, Sakuta M, Osada H, Asami T, Nakano T (2013) A novel mitochondrial DnaJ/Hsp40 family protein BIL2 promotes plant growth and resistance against environmental stress in brassinosteroid signaling. Planta 237:1509-1525

Bemister DH, Semagn K, Iqbal M, Randhawa H, Strelkov SE, Spaner DM (2019) Mapping QTL associated with stripe rust, leaf rust, and leaf spotting in a Canadian spring wheat population. Crop Sci. https://doi.org/10.2135/cropsci2018.05.0348

Bipinraj A, Honrao B, Prashar M, Bhardwaj S, Rao S, Tamhankar S (2011) Validation and identification of molecular markers linked to the leaf rust resistance gene Lr28 in wheat. J Appl Genet. https ://doi.org/10.1007/s13353-010-0026-9

Bolton MD, Kolmer JA, Garvin DF (2008) Wheat leaf rust caused by Puccinia triticina. Mol Plant Pathol. https://doi.org/10.111 1/j.1364-3703.2008.00487.x

Braun HJ, Atlin G, Payne T (2010) Multi-location testing as a tool to identify plant response to global climate change. In: Reynolds MP (ed) Climate change and crop production. CABI, Wallingford, Oxfordshire, UK, Cambridge, MA, pp 115-138

Broman KW, Wu H, Sen S, Churchill GA (2003) R/qtl: QTL mapping in experimental crosses. Bioinformatics. https://doi.org/10.1093/ bioinformatics/btg112

Calvo-Salazar V, Singh RP, Huerta-Espino J, Cruz-Izquierdo S, Lobato-Ortiz R, Sandoval-Islas S, Vargas-Hernández M, German
S, Silva P, Basnet BR, Lan CX, Herrera-Foessel SA (2015) Genetic Analysis of Resistance to Leaf Rust and Yellow Rust in Spring Wheat Cultivar Kenya Kongoni. Plant Dis. https://doi. org/10.1094/PDIS-07-14-0718-RE

Cavanagh C, Morell M, Mackay I, Powell W (2008) From mutations to MAGIC: resources for gene discovery, validation and delivery in crop plants. Curr Opin Plant Biol. https://doi.org/10.1016/j. pbi.2008.01.002

Chen H, Xie W, He H, Yu H, Chen W, Li J, Yu R, Yao Y, Zhang W, He Y, Tang X, Zhou F, Deng XW, Zhang Q (2014) A high-density SNP genotyping array for rice biology and molecular breeding. Mol Plant. https://doi.org/10.1093/mp/sst135

Chu C-G, Friesen TL, Xu SS, Faris JD, Kolmer JA (2009) Identification of novel QTLs for seedling and adult plant leaf rust resistance in a wheat doubled haploid population. Theor Appl Genet. https://doi.org/10.1007/s00122-009-1035-0

Churchill GA, Doerge RW (1994) Empirical threshold values for quantitative trait mapping. Genetics 138:963-971

Churchill GA, Airey DC, Allayee H, Angel JM, Attie AD, Beatty $\mathrm{J}$, Beavis WD, Belknap JK, Bennett B, Berrettini W, Bleich A, Bogue M, Broman KW, Buck KJ, Buckler E, Burmeister M, Chesler EJ, Cheverud JM, Clapcote S, Cook MN, Cox RD, Crabbe JC, Crusio WE, Darvasi A, Deschepper CF, Doerge RW, Farber CR, Forejt J, Gaile D, Garlow SJ, Geiger H, Gershenfeld H, Gordon T, Gu J, Gu W, de Haan G, Hayes NL, Heller C, Himmelbauer H, Hitzemann R, Hunter K, Hsu H-C, Iraqi FA, Ivandic B, Jacob HJ, Jansen RC, Jepsen KJ, Johnson DK, Johnson TE, Kempermann G, Kendziorski C, Kotb M, Kooy RF, Llamas B, Lammert F, Lassalle J-M, Lowenstein PR, Lu L, Lusis A, Manly KF, Marcucio R, Matthews D, Medrano JF, Miller DR, Mittleman G, Mock BA, Mogil JS, Montagutelli X, Morahan G, Morris DG, Mott R, Nadeau JH, Nagase H, Nowakowski RS, O'Hara BF, Osadchuk AV, Page GP, Paigen B, Paigen K, Palmer AA, Pan H-J, Peltonen-Palotie L, Peirce J, Pomp D, Pravenec M, Prows DR, Qi Z, Reeves RH, Roder J, Rosen GD, Schadt EE, Schalkwyk LC, Seltzer Z'e, Shimomura K, Shou S, Sillanpää MJ, Siracusa LD, Snoeck H-W, Spearow JL, Svenson K, Tarantino LM, Threadgill D, Toth LA, Valdar W, de Villena FP-M, Warden C, Whatley S, Williams RW, Wiltshire T, Yi N, Zhang D, Zhang M, Zou F (2004) The Collaborative Cross, a community resource for the genetic analysis of complex traits. Nat Genet. https://doi.org/10.1038/ng1104-1133

Cui F, Zhang N, Fan X-1, Zhang W, Zhao C-h, Yang L-j, Pan R-q, Chen M, Han J, Zhao X-q, Ji J, Tong Y-p, Zhang H-x, Jia J-Z, Zhao G-y, Li J-m (2017) Utilization of a wheat 660K SNP array-derived high-density genetic map for high-resolution mapping of a major QTL for kernel number. Sci Rep. https:// doi.org/10.1038/s41598-017-04028-6

Dakouri A, McCallum BD, Radovanovic N, Cloutier S (2013) Molecular and phenotypic characterization of seedling and adult plant leaf rust resistance in a world wheat collection. Mol Breed. https://doi.org/10.1007/s11032-013-9899-8

Dell'Acqua M, Gatti DM, Pea G, Cattonaro F, Coppens F, Magris G, Hlaing AL, Aung HH, Nelissen H, Baute J, Frascaroli E, Churchill GA, Inzé D, Morgante M, Pè ME (2015) Genetic properties of the MAGIC maize population: a new platform for high definition QTL mapping in Zea mays. Genome Biol. https ://doi.org/10.1186/s13059-015-0716-Z

Douchkov D, Lück S, Baum T, Seiffert U, Schweizer P (2012) Highthroughput phenomics platform for interactions of barley with fungal pathogens. In: Plant \& Animal Genome (PAG-XX), Conference San Diego, Poster, P0115.

Du Z, Che M, Li G, Chen J, Quan W, Guo Y, Wang Z, Ren J, Zhang $\mathrm{H}$, Zhang Z (2015) A QTL with major effect on reducing leaf rust severity on the short arm of chromosome $1 \mathrm{~A}$ of wheat detected across different genetic backgrounds and diverse 
environments. Theor Appl Genet. https://doi.org/10.1007/s0012 2-015-2533-x

Dubcovsky J, Lukaszewski AJ, Echaide M, Antonelli EF, Porter DR (1998) Molecular Characterization of Two Triticum speltoides Interstitial Translocations Carrying Leaf Rust and Greenbug Resistance Genes. Crop Sci. https://doi.org/10.2135/cropsci199 8.0011183X003800060040x

Dyck PL, Kerber ER (1971) Chromosome location of three genes for leaf rust resistance in common wheat. Can J Genet Cytol. https:// doi.org/10.1139/g71-072

Elbasyoni I, El-Orabey W, Baenziger P, Eskridge K (2017) Association mapping for leaf and stem rust resistance using worldwide spring wheat collection. AJOB. https://doi.org/10.9734/ AJOB/2017/38120

Feuillet C, Schachermayr G, Keller B (1997) Molecular cloning of a new receptor-like kinase gene encoded at the $\mathrm{Lr} 10$ disease resistance locus of wheat. Plant J. https://doi.org/10.1046/j.1365313x.1997.11010045.x

Feuillet C, Travella S, Stein N, Albar L, Nublat A, Keller B (2003) Map-based isolation of the leaf rust disease resistance gene Lr10 from the hexaploid wheat (Triticum aestivum L.) genome. Proc Natl Acad Sci USA. https://doi.org/10.1073/pnas.2435133100

Flor HH (1956) The complementary genic systems in flax and flax rust. Adv Genet. https://doi.org/10.1016/S0065-2660(08)60498-8

Flor HH (1971) Current status of the gene-for-gene concept. Annu Rev Phytopathol. https://doi.org/10.1146/annurev.py.09.09017 1.001423

Food and Agriculture Organization of the United Nations (FAO). FAOSTAT. Crops. Latest update: 18/01/2019. Accessed 19/06/2019. URL https://www.fao.org/faostat/en/\#data/QC

Gao L, Turner MK, Chao S, Kolmer J, Anderson JA (2016) Genome wide association study of seedling and adult plant leaf rust resistance in elite spring wheat breeding lines. PLoS ONE. https://doi. org/10.1371/journal.pone.0148671

Gardner KA, Wittern LM, Mackay IJ (2016) A highly recombined, high-density, eight-founder wheat MAGIC map reveals extensive segregation distortion and genomic locations of introgression segments. Plant Biotechnol J. https://doi.org/10.1111/pbi.12504

Gerard GS, Kobiljski B, Lohwasser U, Börner A, Simón MR (2018) Genetic architecture of adult plant resistance to leaf rust in a wheat association mapping panel. Plant Pathol. https://doi.org/10.1111/ ppa. 12761

Gibson G (2012) Rare and common variants: twenty arguments. Nat Rev Genet. https://doi.org/10.1038/nrg3118

Gill HS, Li C, Sidhu JS, Liu W, Wilson D, Bai G, Gill BS, Sehgal SK (2019) Fine Mapping of the Wheat Leaf Rust Resistance Gene Lr42. Int J Mol Sci. https://doi.org/10.3390/ijms20102445

Goyeau H, Lannou C (2011) Specific resistance to leaf rust expressed at the seedling stage in cultivars grown in France from 1983 to 2007. Euphytica. https://doi.org/10.1007/s10681-010-0261-5

Goyeau H, Park R, Schaeffer B, Lannou C (2006) Distribution of pathotypes with regard to host cultivars in French wheat leaf rust populations. Phytopathology. https://doi.org/10.1094/PHYTO $-96-0264$

Hallauer AR, Carena MJ, Miranda Filho JB (2010) Quantitative genetics in maize breeding, [Second edition]. Handbook of plant breeding, vol 6. Springer, New York, Dordrecht, Heidelberg, London

He J, Zhao X, Laroche A, Lu Z-X, Liu H, Li Z (2014) Genotyping-bysequencing (GBS), an ultimate marker-assisted selection (MAS) tool to accelerate plant breeding. Front Plant Sci. https://doi. org/10.3389/fpls.2014.00484

Helguera M, Khan IA, Dubcovsky J (2000) Development of PCR markers for the wheat leaf rust resistance gene Lr47. Theor Appl Genet. https://doi.org/10.1007/s001220051397

Herrera-Foessel SA, Singh RP, Huerta-Espino J, Crossa J, Yuen J, Djurle A (2006) Effect of leaf rust on grain yield and yield traits of durum wheats with race-specific and slow-rusting resistance to leaf rust. Plant Dis. https://doi.org/10.1094/PD-90-1065

Herrera-Foessel SA, Lagudah ES, Huerta-Espino J, Hayden MJ, Bariana HS, Singh D, Singh RP (2011) New slow-rusting leaf rust and stripe rust resistance genes Lr67 and Yr46 in wheat are pleiotropic or closely linked. Theor Appl Genet. https://doi.org/10.1007/ s00122-010-1439-x

Huang BE, George AW, Forrest KL, Kilian A, Hayden MJ, Morell MK, Cavanagh CR (2012) A multiparent advanced generation intercross population for genetic analysis in wheat. Plant Biotechnol J. https://doi.org/10.1111/j.1467-7652.2012.00702.x

Huang BE, George AW (2011) R/mpMap: a computational platform for the genetic analysis of multiparent recombinant inbred lines. Bioinformatics. https://doi.org/10.1093/bioinformatics/btq719

Kankwatsa P, Singh D, Thomson PC, Babiker EM, Bonman JM, Newcomb M, Park RF (2017) Characterization and genome-wide association mapping of resistance to leaf rust, stem rust and stripe rust in a geographically diverse collection of spring wheat landraces. Mol Breed. https://doi.org/10.1007/s11032-017-0707-8

Kertho A, Mamidi S, Bonman JM, McClean PE, Acevedo M (2015) Genome-wide association mapping for Resistance to Leaf and Stripe Rust in Winter-Habit Hexaploid Wheat Landraces. PLoS ONE. https://doi.org/10.1371/journal.pone.0129580

King EG, Macdonald SJ, Long AD (2012) Properties and power of the Drosophila Synthetic Population Resource for the routine dissection of complex traits. Genetics. https://doi.org/10.1534/genet ics.112.138537

Kolmer JA (1996) Genetics of resistance to wheat leaf rust. Annu Rev Phytopathol. https://doi.org/10.1146/annurev.phyto.34.1.435

Kolmer JA (2005) Tracking wheat rust on a continental scale. Curr Opin Plant Biol. https://doi.org/10.1016/j.pbi.2005.05.001

Kover PX, Valdar W, Trakalo J, Scarcelli N, Ehrenreich IM, Purugganan MD, Durrant C, Mott R (2009) A multiparent advanced generation inter-cross to fine-map quantitative traits in Arabidopsis thaliana. PLoS Genet. https://doi.org/10.1371/journal.pgen.10005 51

Krattinger SG, Keller B (2016) Molecular genetics and evolution of disease resistance in cereals. New Phytol. https://doi.org/10.1111/ nph. 14097

Krattinger SG, Lagudah ES, Spielmeyer W, Singh RP, Huerta-Espino J, McFadden H, Bossolini E, Selter LL, Keller B (2009) A putative $\mathrm{ABC}$ transporter confers durable resistance to multiple fungal pathogens in wheat. Science. https://doi.org/10.1126/scien ce. 1166453

Kumar A, Chhuneja P, Jain S, Kaur S, Balyan HS, Gupta PK (2013) Mapping main effect QTL and epistatic interactions for leaf rust and yellow rust using high density ITMI linkage map. Aust J Crop Sci 7:492-499

Lagudah ES, Krattinger SG, Herrera-Foessel S, Singh RP, HuertaEspino J, Spielmeyer W, Brown-Guedira G, Selter LL, Keller B (2009) Gene-specific markers for the wheat gene Lr34/Yr18/Pm38 which confers resistance to multiple fungal pathogens. Theor Appl Genet. https://doi.org/10.1007/s00122-009-1097-z

Lan C, Rosewarne GM, Singh RP, Herrera-Foessel SA, Huerta-Espino J, Basnet BR, Zhang Y, Yang E (2014) QTL characterization of resistance to leaf rust and stripe rust in the spring wheat line Francolin\#1. Mol Breed. https://doi.org/10.1007/s11032-014-0075-6

Lan C, Basnet BR, Singh RP, Huerta-Espino J, Herrera-Foessel SA, Ren Y, Randhawa MS (2017) Genetic analysis and mapping of adult plant resistance loci to leaf rust in durum wheat cultivar Bairds. Theor Appl Genet. https://doi.org/10.1007/s0012 2-016-2839-3

Li G, Xu X, Bai G, Carver BF, Hunger R, Bonman JM, Kolmer J, Dong H (2016) Genome-wide association mapping reveals novel QTL for seedling leaf rust resistance in a worldwide collection of 
winter wheat. Plant Genome. https://doi.org/10.3835/plantgenom e2016.06.0051

Lu Y, Bowden RL, Zhang G, Xu X, Fritz AK, Bai G (2017) Quantitative Trait Loci for Slow-Rusting Resistance to Leaf Rust in Doubled-Haploid Wheat Population CI13227 × Lakin. Phytopathology. https://doi.org/10.1094/PHYTO-09-16-0347-R

Mackay IJ, Bansept-Basler P, Barber T, Bentley AR, Cockram J, Gosman N, Greenland AJ, Horsnell R, Howells R, O'Sullivan DM, Rose GA, Howell PJ (2014) An eight-parent multiparent advanced generation inter-cross population for winter-sown wheat: creation, properties, and validation. G3 (Bethesda) 4:1603-1610. https:// doi.org/10.1534/g3.114.012963

Mammadov J, Aggarwal R, Buyyarapu R, Kumpatla S (2012) SNP markers and their impact on plant breeding. Int J Plant Genomics. https://doi.org/10.1155/2012/728398

Marasas CN, Smale M, Singh RP (2004) The economic impact in developing countries of leaf rust resistance breeding in CIMMYTrelated spring bread wheat. Economics Program Paper 04-01, DF, Mexico

McIntosh RA, Wellings CR, Park RF (1995) Wheat rusts: An atlas of resistances genes. CSIRO Publishing

McIntosh RA, Yamazaki Y, Dubcovsky J, Rogers J, Morris C, Somers DJ, Appels R, Devos KM (2013) Catalogue of gene symbols for wheat: 20013 supplement. https://shigen.nig.ac.jp/wheat/komug i/genes/download.jsp

McIntosh RA, Dubcovsky J, Rogers WJ, Morris C, Xia XC (2017) Catalogue of gene symbols for wheat: 2017 supplement. https://shige n.nig.ac.jp/wheat/komugi/genes/macgene/supplement2017.pdf

Melching JS (1967) Improved deposition of airborne urediospores of Puccinia graminis and P. striiformis on glass slides and on wheat leaves by use of a turntable. Phytopathology 57:647 (abstr.)

Messmer MM, Seyfarth R, Keller M, Schachermayr G, Winzeler M, Zanetti S, Feuillet C, Keller B (2000) Genetic analysis of durable leaf rust resistance in winter wheat. Theor Appl Genet. https://doi. org/10.1007/s001220050055

Milner SG, Maccaferri M, Huang BE, Mantovani P, Massi A, Frascaroli E, Tuberosa R, Salvi S (2016) A multiparental cross population for mapping QTL for agronomic traits in durum wheat (Triticum turgidum ssp. durum). Plant Biotechnol J. https://doi.org/10.1111/ pbi. 12424

Moll E, Walther U, Flath K, Prochnow J, Sachs E (1996) Methodische Anleitung zur Bewertung der partiellen Resistenz und die SASAnwendung RESI. Mitteilungen aus der Biologischen Bundesanstalt für Land- und Forstwirtschaft:p. 4-6

Moll E, Flath K, Tessenow I (2010) Assessment of resistance in cereal cultivars. Design and analysis of experiments using the SASapplication RESI 2. Berichte aus dem Julius-Kühn-Institut 154

Neelam K, Brown-Guedira G, Huang L (2013) Development and validation of a breeder-friendly KASPar marker for wheat leaf rust resistance locus Lr21. Mol Breed. https://doi.org/10.1007/s1103 2-012-9773-0

Neu C, Stein N, Keller B (2002) Genetic mapping of the Lr20-Pm1 resistance locus reveals suppressed recombination on chromosome arm 7AL in hexaploid wheat. Genome. https://doi.org/10.1139/ g02-040

Nover I, Lehmann CO (1967) Resistenzeigenschaften im Gersten- und Weizensortiment Gatersleben. Die Kulturpflanze. https://doi. org/10.1007/BF02095713

Ongom PO, Ejeta G (2018) Mating design and genetic structure of a Multi-Parent Advanced Generation Intercross (MAGIC) population of sorghum (Sorghum bicolor (L.) Moench). G3 (Bethesda) 8:331-341. https://doi.org/10.1534/g3.117.300248

Pascual L, Desplat N, Huang BE, Desgroux A, Bruguier L, Bouchet J-P, Le QH, Chauchard B, Verschave P, Causse M (2015) Potential of a tomato MAGIC population to decipher the genetic control of quantitative traits and detect causal variants in the resequencing era. Plant Biotechnol J. https://doi.org/10.1111/pbi.12282

Pinto da Silva GB, Zanella CM, Martinelli JA, Chaves MS, Hiebert CW, McCallum BD, Boyd LA (2018) Quantitative trait loci conferring leaf rust resistance in hexaploid wheat. Phytopathology. https://doi.org/10.1094/PHYTO-06-18-0208-RVW

R Core Team (2017) R: A language and environment for statistical computing. R Foundation for Statistical Computing, Vienna, Austria. Available at: https://www.R-project.org/

Rasheed A, Wen W, Gao F, Zhai S, Jin H, Liu J, Guo Q, Zhang Y, Dreisigacker S, Xia X, He Z (2016) Development and validation of KASP assays for genes underpinning key economic traits in bread wheat. Theor Appl Genet. https://doi.org/10.1007/s0012 2-016-2743-x

Ren Y, Li Z, He Z, Wu L, Bai B, Lan C, Wang C, Zhou G, Zhu H, Xia $X$ (2012) QTL mapping of adult-plant resistances to stripe rust and leaf rust in Chinese wheat cultivar Bainong 64. Theor Appl Genet. https://doi.org/10.1007/s00122-012-1910-y

Rosewarne GM, Singh RP, Huerta-Espino J, Herrera-Foessel SA, Forrest KL, Hayden MJ, Rebetzke GJ (2012) Analysis of leaf and stripe rust severities reveals pathotype changes and multiple minor QTLs associated with resistance in an Avocet $\times$ Pastor wheat population. Theor Appl Genet. https://doi.org/10.1007/ s00122-012-1786-x

Sacco F, Suárez EY, Naranjo T (1998) Mapping of the leaf rust resistance gene $\mathrm{Lr} 3$ on chromosome $6 \mathrm{~B}$ of Sinvalocho MA wheat. Genome. https://doi.org/10.1139/g98-067

Sallam A, Martsch R (2015) Association mapping for frost tolerance using multi-parent advanced generation inter-cross (MAGIC) population in faba bean (Vicia faba L.). Genetica. https://doi. org/10.1007/s10709-015-9848-Z

Sannemann W, Huang BE, Mathew B, Léon J (2015) Multi-parent advanced generation inter-cross in barley: high-resolution quantitative trait locus mapping for flowering time as a proof of concept. Mol Breed. https://doi.org/10.1007/s11032-015-0284-7

Sannemann W, Lisker A, Maurer A, Léon J, Kazman E, Cöster H, Holzapfel J, Kempf H, Korzun V, Ebmeyer E, Pillen K (2018) Adaptive selection of founder segments and epistatic control of plant height in the MAGIC winter wheat population WM-800. BMC Genomics. https://doi.org/10.1186/s12864-018-4915-3

Serfling A, Krämer I, Perovic D, Ordon F (2013) Erweiterung der genetischen Basis der Resistenzdes Weizens (Triticum aestivum) gegen Braunrost (Puccinia triticina f. sp. tritici). Journal für Kulturpflanzen. https://doi.org/10.5073/JFK.2013.07.02

Sharma C, Saripalli G, Kumar S, Gautam T, Kumar A, Rani S, Jain N, Prasad P, Raghuvanshi S, Jain M, Sharma JB, Prabhu KV, Sharma PK, Balyan HS, Gupta PK (2018) A study of transcriptome in leaf rust infected bread wheat involving seedling resistance gene Lr28. Funct Plant Biol. https://doi.org/10.1071/FP17326

Stadlmeier M, Hartl L, Mohler V (2018) Usefulness of a multiparent advanced generation intercross population with a greatly reduced mating design for genetic studies in winter wheat. Assessment of resistance in cereal cultivars Design and analysis of experiments using the SAS-application RESI 2. Front Plant Sci. https://doi. org/10.3389/fpls.2018.01825

Stadlmeier M, Jørgensen LN, Corsi B, Cockram J, Hartl L, Mohler V (2019) Genetic dissection of resistance to the three fungal plant pathogens Blumeria graminis, Zymoseptoria tritici, and Pyrenophora tritici-repentis using a multiparental winter wheat population. G3 (Bethesda). https://doi.org/10.1534/g3.119.400068

Tsilo TJ, Kolmer JA, Anderson JA (2014) Molecular mapping and improvement of leaf rust resistance in wheat breeding lines. Phytopathology. https://doi.org/10.1094/PHYTO-10-13-0276-R

Turner MK, Kolmer JA, Pumphrey MO, Bulli P, Chao S, Anderson JA (2017) Association mapping of leaf rust resistance loci in a spring 
wheat core collection. Theor Appl Genet. https://doi.org/10.1007/ s00122-016-2815-y

Wang H, Zou S, Li Y, Lin F, Tang D (2020) An ankyrin-repeat and WRKY-domain-containing immune receptor confers stripe rust resistance in wheat. Nat Commun. https://doi.org/10.1038/s4146 7-020-15139-6

William HM, Singh RP, Huerta-Espino J, Palacios G, Suenaga K (2006) Characterization of genetic loci conferring adult plant resistance to leaf rust and stripe rust in spring wheat. Genome. https://doi.org/10.1139/g06-052

Yu J, Holland JB, McMullen MD, Buckler ES (2008) Genetic design and statistical power of nested association mapping in maize. Genetics. https://doi.org/10.1534/genetics.107.074245

Zetzsche H, Serfling A, Ordon F (2019) Breeding progress in seedling resistance against various races of stripe and leaf rust in european bread wheat. Crop Breed Genet Genom. https://doi.org/10.20900 /cbgg20190021

Zhang D, Bowden RL, Yu J, Carver BF, Bai G (2014) Association analysis of stem rust resistance in U.S. winter wheat. PLoS ONE. https://doi.org/10.1371/journal.pone.0103747
Zhang P, Yin G, Zhou Y, Qi A, Gao F, Xia X, He Z, Li Z, Liu D (8425B) QTL mapping of adult-plant resistance to leaf rust in the wheat cross Zhou 8425B/Chinese Spring using high-density SNP markers. Front Plant Sci. https://doi.org/10.3389/fpls.2017.00793

Zhang P, Lan C, Asad MA, Gebrewahid TW, Xia X, He Z, Li Z, Liu D (2019) QTL mapping of adult-plant resistance to leaf rust in the Chinese landraces Pingyuan 50/Mingxian 169 using the wheat 55K SNP array. Mol Breed. https://doi.org/10.1007/s1103 2-019-1004-5

Zhou Y, Ren Y, Lillemo M, Yao Z, Zhang P, Xia X, He Z, Li Z, Liu D (2014) QTL mapping of adult-plant resistance to leaf rust in a RIL population derived from a cross of wheat cultivars Shanghai 3/Catbird and Naxos. Theor Appl Genet. https://doi.org/10.1007/ s00122-014-2346-3

Publisher's Note Springer Nature remains neutral with regard to jurisdictional claims in published maps and institutional affiliations. 